\title{
VEKÂLET SÖZLEŞMESİ BAĞLAMINDA NOXAL SONUÇLU SÖZLEŞME - "HIRSIZ KÖLE OLAYI"
}

\author{
Dr. Özlem SÖĞÜTLÜ ERISGGIN
}

\section{Olay ve Sorunun Ortaya Konulması}

Roma Hukuku'nda kölelik kurumu, bir yönüyle kölenin insan olma niteliğini bir yana bırakarak, ona hukuken eşya gözü ile bakmakta, ancak bir insanın eşya olarak görülmesindeki çelişkiyi aşamadığı için de kölenin suç (delictum) işleyebileceğini kabul etmekteydi. Böylelikle "eşyanın" "suç" işleyebileceği şeklinde bir sonuç ortaya çıkmaktaydı. Bu sonuç, kölenin bir sözleşmenin konusunu oluşturması ve sözleşme nedeniyle köleyi elinde bulunduran tarafa karşı bir delictum işlemesi halinde ise daha özellikli bir şekil almaktaydı. Çünkỉ böyle bir đurum, Roma Hukuku'nun sözleşme ve haksız fiiller alanına egemen olan ilke ve kurumları ile çatışmaktaydı. Ancak, sorunun çözüme kavuşturulması gereği, Romalı hukukçuları ara bir çözüm bulmaya yöneltti ve noxal sonuçlu sözleşme kurumu ortaya çıktı.

Olay aslında basit gözükmektedir: Bir Roma yurttaşı diğer bir Roma yurttaşına bir kölenin satın alınması konusunda vekâlet verir. Vekil görevini yerine getirir ve köleyi satın alır. Roma Hukuku'nda vekil ancak kendi adına ve müvekkili hesabına işlem yapabileceğinden, kölenin satın alınmasından sonra gerekli işlemle mülkiyetini de kazanı ve bu aşamada satın alınan köle, vekile ait bir malı çalar. Konu bu noktada karmaşık bir hal almakta ve sorun bilinen sorumluluk ilkeleri - sözleşmeden doğan sorumluluk, haksız fiilden doğan sorumluluk- ile çözülememektedir.

Sorunun neden sözleşme ya da haksız fiil kurallarına göre çözülemediğinin ortaya konulabilmesi için, önce kölenin hukukî durumunun belirlenmesi gerekmektedir.

- Ankara Üniversitesj Hukuk Fakülteși Roma Özel Hukuku Anabilim Daiı Araştırma Görevliși. 
Roma Hukuku'nda köle, hak ehliyetine sahip olmadığı halde, haksı fiil ehliyetine sahipti. Roma'da, günümüz hukuku anlamında, haksız fïjl-suç ayırımı yapılmamış, kamu suçları (delicta publica)-öze] suçlar (delicta privata) şeklinde bir ayırım yapılmıştı. Kamu suçu işlemesi durumunda köle, ölüm cezası ve benzerleri ile cezalandırılır ve bu ceza devlet organları tarafından uygulanırdı. Kölenin özel suç (kısaca delictum) işlemesi durumunda ise, kişisel öç ve kısas aşamalarında vücuduna el konulması, ihtiyari diyet ve zorunlu diyet aşamalarında ise delictum için belirtenen para cezasm ödemesi söz konusu olabilirdi. Ancak delictum'un kovuşturulmasına ilişkin bu aşamaların hiçbirisi kölenin hukukî durumuna uygun değildi. Çünkü, efendinin köle üzerindeki mutlak egemenliği nedeniyle köleye el konulması imkansızdı. Köle, hak ehliyetine sahip olmadığı için dava ehliyeti de yoktu ve bir delictum işlemesi halinde ona karşı dava açılması söz konusu olamıyordu. Köleye karşı dava açılamaması, kölenin delictum'u nedeniyle ortaya çıkan zarara, zarar görenin katlanması gibi adil olmayan bir sonuç doğuruyordu. Bu adaletsiz sonucu önlemek amaciyla hukuk düzeni, zarar görene, kölenin efendisine karşı açılacak bir dava hakkı tanıdı. Efendiye karşı açılan bu dava noxal dava, efendinin sorumluluğu ise noxal sorumluluk olarak adlandrilmaktaydı. Noxal sorumluluk geregince, efendi ya delictum için belirlenen para cezasınt ödiiyor ya da suçlu köleyi zarar görene birakarak sorumluluktan kurtuluyordu'.

Olayımıza geri döndügüümüzde ise ortaya şöyle bir tabło çıkmaktadır: Kölenin satın almması ve gerekli devir işlemi sonuci kölenin mülkiyeti, Roma'da doğgrudan temsilin tanınmamış olması nedeniyle ${ }^{2}$, vekile geçmekteyđi. Dolayısıyla, burada hırsızlık suçunun işlendiğ̀i anda vekil malikti ve bu dava sadece malike karşı açılabildiği için. müvekkile karşı yöneltilmesi mümkiü değildi. Çünkü, müvekkil bu aşamada kölenin efendisi olmadığından noxal sorumluluk yoluyla vekilin zararı tazmin edilememekteydi. Eğer bir vekâlet sözleşmesi söz konusu olmasaydı ve köle efendisine karşı bir suç işleseydi, burada sorun çımazdı. Çünkỉ efendinin, kölenin öldürỉlmesi de dahil bütün cezalandırma yöntemlerine başvurma hakkı vardı. Roma'da doğrudan doğruya temsil kurumu kabul edilmiş olsaydı, gene böyle bir sorunla karşılaşılmazdı. Çünkü, doğrudan doğruya temsil durumunda kölenin satın alınması ve gerekli devir işlemi ile müvekkil

\footnotetext{
${ }^{1}$ Karadeniz-Çelebican, Ö.: Roma Hukuku (Tarihî Giriş -Kaynaklar- Gene! KavramlarŞahsın Hukuku- Hakların Korunması), 7. basım. Ankara 2001, s. 139. 274-278; Kaser, M.: Das Römısche Privatrecht (das altrömische, das vorklassische und klassische Entwicklungen). 1. Absch., 2. Auf1.. München 1971, s. 163 vd.: Berger, A.: Encyclopedic Dictionary of Roman Law. Philadelphia 1953, s. 600-601: Biondi, B.: Noxa, NDI 12. Milano VTET, s. 449.

${ }^{2}$ Doğrudan temsilin tamınmamış olmasını Gaius. "Egemenliğimiz altında bulunmayan özgür kişiler aracıtığıylá bir şey kazanamayız" sözleriyle belirtmektedir (Gai, lns. II.95) (Bk\%. Karadeniz-Çelebican. s. 263).
} 
kölenin maliki olurdu ve zarar noxal sorumluluk hükümlerine göre karşılanabilirdi.

Vekâlet sözleşmesinden doğan davanın açılması durumunda ise, delictum'dan dogan zararın, sözleşmeden doğan dava ile istenmesi gibi Roma Hukuku sistemine yabancı bir durum ortaya çıkmaktayd. Öte yandan, salt noxal dava olsaydı, müvekkil köleyi terkederek sorumluluktan kurtulabilecekken, burada onu savunmak ve zararı tazmin etmek zorunda birakıliyordu. Bu durum ise noxal davaya egemen olan, 'noxali iudicio inuitus nemo cogitur alium defendere' (hiç kimse noxal davada başkasını savunmaya zorlanamaz) kuralına ${ }^{3}$ ve bu kuralın bir uygulaması niteliğinde olan 'kölenin efendisine kendi değerinden daha fazla bir zarar veremeyeceğt' kuralına ters düşmektedir.

Soruna ilişkin Roma Hukuku kaynaklarına bakıldığında ise, biri Africanus'a (D.47.2.62.5), digeri ise Paulus'a (D.17.1.26.7) ait iki Digesta metni ile karş̧laşılmaktadır. Aşă̆ıda incelenen metinlerin her ikisinde de, müvekkil, kölenin hırsız olduğunu biliyorsa, vekâlet sözleşmesinden doğan dava (actio mandati contraria) ile vekilin hırsızlıktan doğan zararını gidermekle yúkümlü tutuluyordu. Müvekkilin kölenin hırsız olduğunu bilmemesi durumunda ise, metinler arasında görüş farklılığ bulunmaktadır. D.47.2.62.5 (Afr.)'de müvekkil, kölenin hırsız olduğunu bilsin ya da bilmesin, köleyi terketme hakkına sahip olmaksızın vekilin zararından sorumlu tutulurken; D.17.1.26.7 (Paul.)'de müvekkilin kölenin hırsız olduğunu bilmemesi durumunda köleyi noxal terketme hakkının bulunduğu kabul edilmekteydi.

Metinlerde yer alan görüş farklılığı ve gene metinlerde sözleşmeden doğan dava hakkı ile efendiye zarar veren köleyi terketme hakkının (noxal sonuçlu sözleşme) tanınmış olması, bunlar üzerinde çeşitli tartışmalara yol açmıştır. Çalışmanın konusunu, yukanıda aktarılan soruna ilişkin metinler, metinler arasındaki görüş farklılığının nedenleri ve Romanistlerin. Klasik Hukuk Dönemi'nde noxal sonuçlu sözleşmeden doğan davanın var olup olmadığı tartışmaları oluş̧urmaktadır.

\section{Olaya İlişkin Metinlerin İncelenmesi}

\section{Africanus'un Metni}

D.47.2.62.5 (Afr.): "Quod vero ad mandati actionem attinet, dubitare se ait, num aeque dicendum sit omni modo damnum praestari debere, et quidem

${ }^{3}$ D.9.4.33.1 (Pomp.); Bjondi, Noxa, s. 450. 
hoc amplius quam in superioribus causis servandum, ut, etiamsi ignoraverit is, qui certum hominem emi mandaverit, furem esse, nihilo minus tamen damnom decidere cogatur. iustissime enim procuratoren allegare non fuisse se id damnum passurum, si id mandatum non suscepisset: idque evidentius in causa depositi apparere, nam licet alioguin aequum videatur non oportere cuiquam plus damni per servum evenire, quam quanti ipse servus sit, multo tamen aequits esse nemini officium suum, quod eius, cum quo contraxerit, non etiam sui commodi causa susceperit, damnosum esse, et sicut in superioribus contractibus, venditione locatione pignore, dolum eius, qui sciens reticuerit, puniendum esse contrahatur ipsis potius damnosam esse debere, nam certe mandantis culpam esse, qui talem servum emi sibi mandaverit, et similiter eius qui deponat, quod non fuerit diligentior circa monendum. qualem servim deponeret".

D.47.2.62.5 (Afr.): "Ancak vekâlet sözleşmesinden doğan davaya ilişkin olarak, zararın, her durumda tazmin edilmesi gerektiǧi hususunda kuşku duyduğunu söyler, acaba, bu, yukarıdaki davalardan daha geniş mi yorumlanmalıdır? Belli bir insanın (kölenin) satın alınması için vekâlet veren kimse, hırsız olduğunu bilmese bile, gene de zararı gidermekle yiikümlü tutulmalıdır. Çünkiu, haklı olarak, mandatum'u üstlenmemiş olsaydı, procurator'un bu zarara katlanmayacağı ileri sürülür. Bu, depositum (vedia) davasında daha açık göziukmektedir. Çünkỉ herhangi birine, kölesi aracılığı ile kölenin değerinden daha fazla bir zarar gelmemeși gerektiği haklı görülür. Gene de kendi yararı için değil de, sözleşme yaptığı kişinin yararı için üstlendiğgi görev, hiç kimse için daha fazla bir zarar getirmemelidir. Satış. kira, rehin gibi yukarıdaki sözleşmelerde, bile bile susan kişinin hilesinin cezalandırılması gerektiği söylendiği gibi, gene bunlarda daha çok kendileri için sözleşme yaptığı kimselerin kusurunun zarar vermiş olması gerekir. Çünkü kuşkusuz, vekâlet veren, kendisi için böyle bir kölenin satın alınması görevini verdiği için kusurludur ve benzer şekilde vedia verenin de dikkatli olmaması nedeniyle kusuru vardır".

Africanus'a ait olan ve Julianus'un görüşlerini aktaran bu metin gereğince müvekkil, belli bir kölenin satın alınmasını konu edinen vekâlet sözleşmesi bağlamında hırsızlık suçunun mağduru haline gelen vekilin zararını sözleşmeden doğan dava ile gidermekle yükümlï idi. Metne göre, müvekkilin kölenin hırsız olduğunu bilip bilmemesi sorumluluğun kapsamını belirleme ve sonuçlarıı değiştirmede bir etkiye sahip değildi. Diğer bir deyişle, sözleşmeden doğan davanın noxal sonucu yoktu ve müvekkil, kölenin hırsız oldugunu bilsin ya da bilmesin, vekilin bu hırsızlık nedeniyle ortaya çıkan tüm zararını actio mandati ile gidermekle yükümlïidüi. 
Metinde iki farklı kuralın yinelendiği görülmektedir. Bunlar; "hiç kimse, kölesinin haksız fiili nedeniyle kölesinin değerinden daha fazla bir zarart tazmin etmekle yükümlï tutulamaz" ile "hiç kimse, dostluğa, hatıra dayanlarak üstlenilen ve sadece sözleşmenin diğer tarafının yararının olduğu bir sözleşme dolayısıyla zarara katlanamaz"4 kuralıdır. Metinde yer alan "çünkü herhangi birine, kölesi aracılığı ile kölenin değerinden daha fazla bir zarar gelmemesi gerektiği haklı görülür. Gene de kendi yararı için değil de, sözleşme yaptığı kişinin yararı için üstlendiği görev, hiç kimse için daha fazla bir zarar getirmemelidir" ifadesinden hareketle, Juliantus'un bu ilkelerden ikincisine üstünlük tanıdığı söylenebilir ${ }^{5}$. Julianus'a göre, vekilin katlanmak zorunda olmadı̆g bütün zararlar müvekkil tarafından üstlenilmelidir. Bunlardan birisi de, satın alınması hususunda yetki verilen kölenin vekile karşı işlediği hrrsızlık suçu nedeniyle vekilin uğradığı zarardir.

\section{Paulus'un Metni}

Paulus'a ait olan ve Neratius'un görüşlerini aktaran diger bir metinde ise aynı konunun farklı bir düzenlemesi ile karşılaşılmaktadır.

D.17.1.26.7 (Paul.): "Sed servus, quem mandatu meo emeras, furtum tibi fecisset, Neratius ait mandati actione te consecuturum, ut servus tibi noxae dedatur, si tamen sine culpa tua id acciderit: quod si ego scissem talem esse servum nec praedixissem, ut possis praecavere, tunc quanti tua intersit, tantum tibi praestari oportet".

D.17.1.26.7 (Paul.): "Eğer benim vekâletimle satın almış olduguun köle, senden bir şey çalmış olsa, Neratius, senin actio mandati açabileceğini söyler ve kölenin sana noxa olarak verilmesi gerekir, bunun, senin kusurunun dışında olması koşulu ile, eğer ben böyle bir köle olduğunu bilseydim ve onun hırsızıı̆ından korunabilesin diye sana önceden söylememiş olsaydım, o zaman senin menfaatin neyi gerektiriyorsa, sana o kadar ödenmesi gerekir".

4 Utilitas (yarar, fayda) ilkesi için bkz. Käbler, B.: Die Konträrklagen und das Utilitätsprinzip, SZ 38, Weimar 1917, s. 73 vd.; Nörr, D.: "Die Entwicklung des Utilitätsgedankens im römischen Haftungsrecht", SZ 73, Weimar 1956, s. 68-1 19.

${ }^{5}$ Aynı görüş için bkz. Stein, P.: Fault in the Formation of Contract in Roman Law and Scots Law. Edinburgh 1958, s. 155-156; Pernice, A.: LABEO, Römisches Privatrecht im ersten Jahrhunderte der Kaiserzeit, Bd. II, 2, 1, Halle 1900, s. 228; Buckland, W. W.: The Roman Law of Slavery, Cambridge 1908, s. 125; Mac Cormack, G.: "The Thievish Slave", RIDA 19, 3. Seri, Bruxelles 1972, s. 359; Watson, A.: Contract of Mandate in Roman Law, Oxford 1961, s. 161 . 
Neratius'a göre, satın alımması hususunda yetki verilen kölenin vekile karşı hırsızlık suçunu işlemesi durumunda, vekil vekâlet sözleşmesinden doğan davayı açma hakkına sahipti. Müvekkil ise, vekilin kendisine karşı açtığı mandati contraria davasında, köleyi zarar gören vekile bırakarak, daha ağı bir sorumluluktan kendisini kurtarabilirdi. Metnin ikinci bölümünde ise Paulus, vekalet verenin, kölenin hırsız olduğunu bilmesi durumunda noxal terketme hakkına sahip olmaksızın, sözleșmeden doğan dava ile zararını gidermekle yükümlü olduğunu belirtmektedir.

Sonuç olarak Paulus'un metninde, müvekkilin noxal terketme hakkına sahip olmaksızın vekilin hırsızlıktan dogan zararını actio mandati ile gidermesi gereği kölenin hırsız olduğunu bilmesi koşuluna bağlanmışken; Africanus'un metninde müvekkil, kölenin hursız olduğunu bilsin ya da bilmesin, noxal terketme hakkına sahip olmaksızın vekilin zararından sorumlu tutulınuş ve sorumluluğun ağırlaştırılması sözleşmeden bir yarar elde etmeyen vekilin zarara katlanmaması gerektiği ilkesine dayandırılmıştır.

\section{Görüişler}

Metinlerin Klasik Hukuk Dönemi'ne ait olup olmadığı, diğer bir ifadeyle, noxal sonuçlu sözleşme kurumunun bu döneme ait olup olmadı tartışmasıyla birlikte, metinlerdeki görüş farklılığının nereden kaynaklanabileceğine ilişkin görüşlerin de irdelenmesi gerekmektedir.

\section{Metinler Arasındaki Çelişkiye İlişkin Görüşler}

Stein, D. 47.2.62.5 (Afr.) ile D. 17.1.26.7 (Paul.) arasındaki çelişkinin, metinler üzerinde çalışan Compilator'lar tarafından değil, Klasik Hukuk Dönemi'ne damgasm vuran Sabinianus Mektebi ile Proculianus Mektebi arasındaki görüş farklıı̆̆ından kaynaklanabileceğini ileri sürmektedir ${ }^{6}$.

Yazara göre, her iki metinde de müvekkil, kölenin hırsız olduğunu bilmesi durumunda, noxal terketme hakkı olmaksızın, sözleşmeden doğan dava ile hırsızlık nedeniyle vekilin uğradığı zararı tazmin etmekle yükümlü tutuluyor. Müvekkilin kölenin hırsız olduğunu bilmemesi durumunda ise. metinler arasında sorumluluğun kapsamı bakımından farklılık ortaya çıkıyor.

Stein, bu farklılı̆̆ın Sabinianus Mektebine dahil olan Julianus ile Proculianus Mektebine dahil olan Neratius arasındaki anlaşmazlıktan kaynaklanabileceğini söylüyor. Stein, sorumluluk alanında kullanılan iki

\footnotetext{
"Stein. s. I58-159; aymı görüş için bkz. Lambert, J. N.: "Une opposition peu connue entre Sabiniens et Proculiens, Studi in Onore di Emilio Betti. Vol. IIt, Milano 1962. s. 281 vd.
} 
ilkenin aynı olayda karşı karşıya geldiłini, bu ilkelerden her birinin ise Hukuk Mektepleri tarafından benimsendigi görủşündedir. Buna göre, Julianus, 'sözleşmeden yarar sağlayan tarafın, sözleşmeden hiçbir yarar elde etmeyen tarafin zararınt gidermekle yükümlü olacăğ ilkesini' benimserken; Neratius, 'delictum işleyen kölenin, bu fiil nedeniyle efendisine kendi degerinden daha fazla zarar veremeyece ğ $\imath^{\prime}$ jlkesini benimsemiştir?

Benzer bir yorum yapan Medicus da, her iki metnin bir yararın (interesse), bir talebin korunmasına yönelik görüş farklılığını ortaya koyduğunu belirtmektedir ${ }^{\mathrm{r}}$.

Basilika ${ }^{91}$ da her iki metin bağdaştırılmaya çalışılmış ve Africanus'un metninin belli bir kölenin (certum hominem) satun alınmasını; Paulus'un metninin ise herhangi bir kölenin satın alınmasını konu edindiği şeklinde bir yorum getirilmiştir. Buna göre, müvekkil belli bir kölenin satın alınması konusunda vekili yetkilendirdiği için, kölenin vekile verdiği bütün zararlardan sorumludur. Çünkü, müvekkil, bu kölenin hırsız olduğu hakkında bilgi sahibi olmadığı için kusurludur. Herhangi bir kölenin satın alınmasını konu edinen vekâlet sözleşmesinde ise vekil, köleyi satın alırken gerekli araştırmayı yapmalıydı. Araştırma yapmadan hırsız bir köle satın aldığı için kusurludur, dolayısıyla, ancak noxal sonuçlu sözJeşmeden doğan dava ile zararmın giderilmesini talep edebilir.

Böyle bir yorum, sorumluluğu kusura dayandırmaya çalışan Basilika ögretisine uygun dưşmekte, fakat Klasik Hukuk Dönemi'ndeki sorumluluk anlayışıyla bağdaşmamaktadır. Çünkü, Klasik Hukuk Dönemi'nde müvekkilin sorumluluğu custodia (gözetim) ${ }^{10}$ sorumluluğu idi ve bu dönemde kusur henüz böylesine teknik bir anlam kazanmamıştı. Kusur (culpa) kavramı yeterince tanımlanmamıs, kimi metinlerde culpa ile her türlüi kusur (kasıt ve ihmal) belirtilmişti. Ayrıca, bu dönemde culpa'nın derecelendirilmesi de (culpa levis, culpa lata gibi) yapılmamışt1" ${ }^{\prime \prime}$. KlâsikSonrası Hukuk Dönemi'ni etkileyen Doğu Roma Ô̆gretisi, culpa lata ve culpa levis ayrımını yaparak, bu kavramları tanımlama yoluna gitmiştir ${ }^{\prime 2}$.

\footnotetext{
${ }^{7}$ Stein, \$. I58-159

${ }^{8}$ Medicus, D.: ld Quod Interest, Studien $2 u m$ römischen Recht des Schadensersatzes, Köln 1962, s. 195, dn. 26.197.

${ }^{9}$ Bas. 60.12.61 (Kübler, s. 97, dn.l'den naklen)

11 Custodia sorumluluğu hakkında ayrıntılı bilgi için bkz. Zilelioğlu, H.: Roma Hukukunda Gözetim (Custodia) Sorumluluğgu, Yayınlanmamış Doktora Tezi, Ankara 1985.

"Lenel, O.: "Culpa lata und culpa levis", SZ 38, Weimar 1917, s. 270-271.

${ }^{12}$ Lenel, SZ 38 , s. 271.
} 
Noda ${ }^{13}$, Africanus'un metninde, belli bir kölenin satın alıması konusunda yetki veren müvekkilin custodia sorumluluğu nedeniyle sözleşmeden doğan dava ile vekilin zararını gidermesi durumunun düzenlendiğini; herhangi bir kölenin satın alınmasını konu edinen Paulus'un metninde ise, herhangi bir kölenin hırsız çıkması riskini vekilin taşıması gereğinden hareket edildiğini ve dolayısıyla da kölenin hırsız olduğunu bilmemesi durumunda noxal sonuçlu sözleşmeden doğan dava ile sorumlu tutulacă̆ 1 hususunun düzenlendiği görüşüündedir.

\section{Metinlerin Hangi Döneme Ait Olduğuna İlişkin Görüşler}

İIgili metinler üzerinde Compilator'ların çalıştıkları Romanist'ler ${ }^{14}$ tarafından kabul edilmekle birlikte, tartışma, Klasik Hukuk Dönemi'nde noxal sonuçlı sözleşmeden doğan davanın kabul edilip edilmediği konusunda ortaya çıkmaktadır.

Bir görüşse göre, Klasik Hukuk Dönemi'nde noxal sonuçlu sözleşmeden doğan davanın açılabileceği, dolayısıyla metinlerde bu konuyla ilgili bölümlerin interpolatio ${ }^{151}$ ya uğramadığı ve Klasik Dönem hukukçularının görüşlerinin Compilator'lar tarafından korunduğu savunulurken: diğer görüşe göre, Klasik Hukuk Dönemi'nde noxal sorumluluğun salt hakssz fiil davalarma özgî olduğu, noxal sonuçlu sözleşmeden doğan davaya Iustinianus Dönemi'nde izin verildiği, dolayısıyla bu metinlerin interpolatio'ya uğradı̆̆ı ileri sürülmektedir.

1. Noda, R.: Die Haftung des Auftraggebers für Schäden des Bcauftragten. Zur Entstehung des $\$ 650$ (3) des japanischen BGB, Fukuoka-Symposjum 1991 s. $210-211$.

"Metinlerin dil açısından değgerlendirilınesi ve hangi cümlelerin interpolatio'ya uğgadığı ve eklenen kelimelerin hangileri olduğu doğrultusundaki açıklamalar için bkz. Lenel, $0 .:$ Afrikans Quästionen Versuch einer kritischen Palingenesie, SZ 51, Weimar 1931, s. 47; Eisele, H. J.: Die Haftung des Mandanten fi.t Schaden des Mandatars, AcP 84. Leipzig 1895. s. 328, 341, 344; Bund, E.: Untersuchungen zur Methode Julians, Koin 1965, s. 59-60; Honsell, H.: Quod Interest im Bonae-Fidej-Iudicium, Studien zum römischen Schadensersatzrecht, München 1968. s.158, dn. 37: Thomas, J. A.: Pro Noxal Surrender", Labeo Rassegna di Diritto Romano 17, Napoli 1971, s. 27 vd,; Stein, s. 155-156; Pernice, s. 228-229; Watson. s. 160 -161.

${ }^{15}$ Interpolatio: M. S. 527 yılında Doğu Roma İmparatorluğu'nun başına geçen imparator Iustinianus, eski büyük Roma İmparatorluğu'nu yeniden canlandırmak amacıyla bir kanunlaşııma hareketine girişti. Bıł kanunlaştımma hareketinde Klâsik Dönem hukukçularının eserleri esas alındı. Klâsik Dönem hukukçulatının eserlerini derleyen ve Compilator olarak adlandırtlan hưkukçular, Klâsiklerin eserlerini özgün haliyle Iustiniamus Dönemi'ne aktarmadilar. Compilator'lar, Iustinianus Dönemi'nde geçerli olan hukuk düşünccsine, gelişen ve değişen toplumsal koşullara uygun olarak, bu eserlerde eklemeler, çıarmalar, değ işiklikler yaptular. Compilator'lar tarafından Klâsik Hukuk Dönemi'ne ajt metinlerde yapılan bu ckleme. çıkarma ve deģişiklikler interpolatio olarak adlandırıtmaktadır (Karadeniz-Çelebican, s. 42 vd. özeliikle s. 54-55). 


\section{a) Klasik Hukuk Dönemi'ne Ait Olduğunu Savunan Görüş}

$\mathrm{Bu}$ görüşii benimseyen yazarlardan Stein, metinlerin interpolatio'ya uğradığını kabul etmekle birlikte, aynı zamanda da Klasik Hukuk Dönemi hakkında bir görüntü sunduğunu ileri sürmektedir. Hukukçuya göre, D. 47.2.62.5 (Afr.)'in ilk bölümü Klasik Hukuk Dönemi'ne aittir, metnin ikinci bölümünde ise Compilator'lar tarafundan işlendiğini gösteren çeşitli eklemeler yer almaktadir ${ }^{16}$.

Yazar, interpolatio'ya uğramadığını ve dolayısıyla da Julianus'un görüşlerini aktardı̆̆ını ileri sürdüğü D. 47.2.62.5 (Afr.)'in birinci bölümünden hareketle, Julianus'un, vekilin hırsızlıktan kaynaklanan zararının vekâlet sözleşmesinden doğan dava aracılı̆̆ıyla müvekkil tarafından, kölenin hırsız oldugunu bilsin ya da bilmesin, giderilmesi gerektiği görüşünde olduğunu; D.17.1.26.7 (Paul.)'den hareketle ise, Neratius'un mïvekkilin bilgisi olmaması durumunda, köleyi terketme hakkını tanıyan sözleşmeden doğan davaya izin verilmesi gerektiği görüşünde olduğunu kabul etmektedir ${ }^{17}$.

Bu görüşü savunan yazarlardan Kübler, D. 47.2.62.5 (Afr.)'de yer alan ve müvekkili, kölenin hırsızlık niyetini bilsin ya da bilmesin, terketme hakkı olmaksızın actio mandati contraria'yla sorumlu tutan cümlenin Klasik Hukuk Dönemi'ne ait oldugunu belirtmektedir. Yazara göre, vekil, üstlendiği işi müvekkilin menfaati dogrultusunda ücretsiz olarak yerine getirmekle yükümlü olduğu için, bir yarar elde etmemekteydi. Vekâlet sözleşmesinden sadece kendisi yarar elde eden müvekkil ise, Klasik Hukuk Dönemi'nde kasıt (dolus) ve ihmal (culpa) yanında, beklenmeyen halden de (casus) sorumluydu. Klasik Hukuk Dönemi'nde hırsızlık casus sayıldı̆̆ına göre vekilin, müvekkilin terketme hakkı olmaksızın sözleşmeden doğan dava ile zararının giderilmesi, bu dönemin sorumluluk anlayışına uygun dïşsmektedir ${ }^{18}$.

Medicus $^{19}$, D. 47.2.62.5 (Afr.)'in Compilator'lar tarafından çalışıldığını gösteren birçok izler taß̧ıdığını, fakat her durumda "non suscepisset' $\mathrm{e}^{20 "}$

\footnotetext{
16 "Iustissime ile başlayan ve apparere ile biten cümlenin Compilator'lara ait olduğunu belirten cümle" için bkz. s. 155; "procurator kelimesinin bu dönemde vekil anlamında kullanılmadığı ve bir ekleme olduğunu belirten cŭmle" için bkz. s. 155; diğer sōzleşmeler ile vekâlet sŏzleşmesini karşıłaştıran metnin ikinci bölümnünün Compilator'ların ürünü olduğu görüşü için ise bkz. s. 156.

${ }^{17}$ Stein, s. 156, 161 .

${ }^{18}$ Kübler, s. 94-95.

${ }^{19}$ Medicus, s. 195.

${ }^{20} \mathrm{Bkz}$. Vekâlet ve vedianın karşılaştırıldığı cümlenin başladığı kısım.
} 
kadar olan bölümün Klasik Hukuk Dönemi'nin düşüncesini içerdiǧini ve bu kısımda interpolatio olmadığı görişüundedir.

Bu görüşe katılan yazarlardan Buckland, noxal terketmeye izin veren sözleşmeden doğan dava kurumunun Klasik Hukuk Dönemi'ne ait olduğu, metinlerde Klasik Dönem hukukçularının görüşlerinin korunduğu ve interpolatio'ya uğrayan kısımların noxal sonuçlu sözleşmeden doğan davaya ilişkin olmadığı görusşündedir ${ }^{21}$.

Buckland'a göre, vekil, müvekkile karşı vekâlet sözleşmesinden doğan davayı açarak, hırsızlık nedeniyle ortaya çıkan zararının tazmin edilmesini isteme hakkına sahipti. Müvekkilin kölenin hırsız olduğu hakkında bir bilgisinin varlığg ya da yokluğu, onun sorumluluğunu belirlemede etkili değildi. Müvekkil, köleyi terketme hakkına sahip olmaksızın ortaya çıkan zararı gidermekle yükümlüydü. Çünkü, vekil, ücretsiz olarak üstlendiği iş nedeniyle bir zarara uğramamalıydı ${ }^{22}$. Hırsızlıktan doğan dava (actio furti) bu olayda açılamazdı. Çünkü, hırsızlık suçunun işlendiği anda, hırsızlığın mağduru hırsızın malikiydi ve bu durum actio furtinin açılmasııı engellerdi ${ }^{23}$.

Ayrica, Buckland, belli bir kölenin satın alınmasm konu edinen D. 47.2.62.5 (Afr.)'den hareketle, müvekkilin böyle bir kölenin satın alınması konusunda talimat verdiği için kusurlu oldugunu, dolayısıyla noxal terketme hakkının bulunmadığ̆ını ileri sürmektedir. Buckland görüşüne dayanak olarak, hırsız bir kölenin satın alınması dogrultusunda talimat veren müvekkil ile hırsız bir köleyi saklanması için vedia verenin aynı şekilde kusurlu olduğunu belirten D. 47.2.62.5 (Afr.)'in son cümlesini almaktadır ${ }^{24}$.

D. 47.2.62.5 (Afr.): "... Çüıkü kuşkusuz, vekâlet veren, kendisi için böyle bir kölenin satın alınması görevini verdiği için kusurludur ve benzer şekilde vedia verenin de dikkatli olmaması nedeniyle kusuru vardır."

Ancak, bu cümlenin interpolatio ve sorumluluğu kusur temeline dayandırmaya çalışan Compilator ların bir ürünü olduğu kabul edilmekte: müvekkilin noxal terketme hakkı olmaksızın sorumlu tutulması ise, kusurlu davranışıyla değil, vekilin sözleşmeden bir yarar elde etmemesiyle açıklanmaktadır ${ }^{25}$.

${ }^{21}$ Buckland, Slavery, s. 124-126.

${ }^{22}$ Buckland. Slavery. s. 124-125.

${ }^{27}$ Buckland, W. W.: Digest XLVII 2 (De Furtis) and the Methods of the Compilers. TVR 10. Groningen 1930. s. 123-124.

${ }^{24}$ Buckland. Slavery, s. 125.

${ }^{25}$ Bkz. Kübler. s. 97-98; Bund, s. 90; Nörr, s. 95-96; Stein. s. 156; Medicus, s. 196. 
Buckland'in görüşlerine benzer bir görüş ileri süren Mac Cormack'a göre, muivekkil, vekili, belli bir köleyi satm almakla görevlendirirken, bu köle hakkında gerekli soruşturmayı da yapmak zorundaydı. Muivekkilin, kölenin karakteri hakkında yeterli bilgiyi edinmemesi halinde kusur söz konusuydu ve bu durumda, vekilin, hırsızlık nedeniyle ortaya çıkan zararının, sözleşmeden doğan dava gereğince giderilmesi gerekiyordu ${ }^{26}$.

\section{b) Iustinianus Dönemi'ne Ait Olduğunu Savunan Görüş}

Bu görüşuin en güçlü temsilcisi olan Biondi'ye göre, noxal terketmeye izin veren sözleşmeden doğan dava fikri Klasik Hukuk Dönemi'ne değil, Compilator'lar Dönemi'ne aittir. Klasik Hukuk Dönemi'nde bir sözleşmeye dayanarak köleyi elinde bulunduran tarafa karşı, kölenin hırsızlık suçunu işlemesi durumunda, sözleşmenin diğer tarafı hırsızlık suçunun işlendiǧini biliyorsa, ona karşı hursızlıktan doğan dava (actio furti); bilmiyorsa noxal sonuçlu hırsızlıktan doğan dava (actio furti noxalis) açılırd $1^{27}$.

Biondi'ye göre, Klasik Hukuk Dönemi'nde köleyi terketme hakkı tanıyan sözleşmeden dogan dava söz konusu olamazdı. Çünkü, noxal terketme salt haksız fiil davalarına özgü idi. Ancak, Compilator'lar Klasik Hukuk Dönemi'nde haksız fiil alanında kalan ve haksız fiilden doğan davanın $m ı$ yoksa sözleşmeden doğan davanın $m ı$ açılacağının saptanmasında güçlïk çekilen bu tür olayları sözleşme alanına aktarmak istediler ve noxal sonuçlu sözleşmeden doğan davayı yaratarak, bunu, bu tïr olayların düzenlendiği metinlere yerleştirdiler. Bu metinlere göre, eğer efendi kölenin hırsiz olduğunu biliyorsa (dominus sciens servum furem esse), mağdurun hırsızlıktan kaynaklanan zararını sözleşmeden doğan dava ile gidermekle yükümlï tutuldu. Kölenin hırsızlı̆̆ını bilmemesi (dominus ignorans) durumunda ise, ona karş1 noxal terketme hakkı tanıyan sözleşmeden doğan dava açılıyordu ${ }^{28}$.

Bu görüşe katılan hukukçulardan Heldrich, Roma Hukuku'nda doğrudan temsil bilinmediģi için, geçici de olsa kölenin maliki olan vekile actio furti noxalis'i açma hakkının tanınması gerektiğini ve başka bir hukukî araçla da vekilin zararının giderilemeyeceğini belirtmekte ve D. 47.2.62.5 (Afr.)'in interpolatio'ya uğradığını ileri sürmektedir ${ }^{29}$.

\footnotetext{
${ }^{26}$ Mac Cormack. s. 360-361.

${ }^{27}$ Biondi, B.: Iudicia Bonae Fjdej I, Palermo 1920, s. 97 vd.

${ }^{28}$ Biondi, ludicia, s. 97 vd., s. 106.

${ }^{2}$ Heldrich, K.: Das Verschulden beim VertragsabschluB im klassischen römischen Recht und in der späteren Rechtsentwicklung, Leipzig 1924, s. 25-26.
} 
Heldrich, noxal sonuçlu sözleşmeden doğan dava kurumunun Klasik Hukuk Dönemi'ne ait olduğunu savunan görüşü, vekâlet sözleşmesinde masraf ve zarar ayrımı yaparak çürütmeye çalışmaktadır. Heldrich'e göre, vekil, üstlendiğ i iş nedeniyle iradî olarak kendi malvarlığında bir eksilmeye neden olmuşsa, bu eksilme bir mastaftır. Doğruluk ve dürüstlük kurallarına göre bu masrafların zorunlu olduğu kabul ediliyorsa, vekil bunları müvekkilden talep edebilir. Satın alınması için vekâlet verilen kölenin vekile karşı hırsızlık suçunu işlemesi ise, vekilin iradesi dışında malvarlığında ortaya çıkan bir eksilmedir. Bu eksilme, masraf değil, zarardır. Bu tür bir zararın ise, vekâlet sözleşmesinden doğan dava ile giderilebileceği düşüncesi Klasik Hukuk Dönemi'ne yabancıdır ${ }^{\text {in, }}{ }^{31}$.

Heldrich, D. 17.1.26.7 (Paul.)'nin ise interpolatio'ya uğradığını, fakat içerik olarak Klasik Dönemi yansıttığı görüşündedir. Yazara göre, "... Neratius ait mandati actione te consecuturum ..." "Neratius, senin actio mandati açabilcceğini söyler ..." ifadesinde yer alan mandati actione, interpolatio'dur. Burada aslinda olması gereken dava adı actio furti'dir (hrrsizlıktan doğan dava). Buna göre, müvekkil kölenin hırsizlığın bilmiyorsa noxal sonuçlu actio furti'den sorumludur. Eğer biliyorsa, bu durumda ne sözleşmeden ne de hırsızlıktan doğan dava açılır, sadece iyiniyete aykırı davranışlara karşı açılan actio de dolo söz konusu olabilit ${ }^{32}$.

\section{Sonuç}

Roma Hukuku, kanunlarla degil, Praetor'ların hukuk yaratması ve hukukçuların faaliyetleri ile gelişmiştir. Özellikle Klasik Hukuk Dönemi olarak adlandırılan ve günümüz hıkuk düzenlerini de etkileyen dönemde hukukçuların hukuk hayatına çok önemli katkıları olmuştur.

Roma Hukuku'nun gelişimini sağlayan hukukçular, belli bir yöntem kullanmamış ve hér biri, kendine özgü bir çalışma biçimi benimsemiştir. Hukukçular önlerine gelen somut olay bağlamında hukuksal faaliyette bulundukları için, aynı olay için farklı önerilerin getirildiğini ve görüş̧ farklılıklarımın olabileceğini metinlerden anlıyoruz. Bu durumun farklı felsefî görişe sahip Sabinianus ve Proculianus olarak adlandırılan iki Hukuk Mektebinin de ortaya çımasına yol açtığı bilinmektedir.

Heldrich, s. 26-27.

" Klasik Hukuk Dönemi'nde müvekkilin sorumluiuğınun custodia sorumluluğu olması ve müvekkile bir kusur atfedilmese dahi vekilin uğradığ zarardan belirli bir sınıra kadar (sınır mücbir nedendir) sorumlu olması nedenleriyle bu görüşe katılmak mümküı değildir (aym doğrultuda bkz. Eisele, s. 345; Kübler, s. 94).

${ }^{32}$ Heldrich, s. 30 . 
Bu nedenle, metinler arasında Klasik Hukuk Dönemi'ne ilişkin görüş farklılıklarının bulunması doğal bulunabilir. $\mathrm{Bu}$ durum, söz konusu metinlerin Klasik Dönem hukukçularının görüşlerini yansıttığı görüşüne katılmak için yeterli görülebilir. Metinler üzerinde Compilatorilar tarafından çalışıldığı konusunda bir şüphe bulunmadığına göre, Compilator'ların neden metinleri eşgüdümlü bir hale getirmediği sorusu akla gelmektedir. Compilator'lar, metinlere Iustinianus Dönemi düşüncesine uygun olarak kusur ilkesini yerleştirirken, aynı zamanda da Klasik Dönem hukukçuları arasındaki görüuş farklılığına işaret etmek ve bunları korumak istedikleri düşünülebilir. Kaldı ki, metinlerdeki görüş farklılığı, vekilin zararının hangi dava ile giderileceği sorunundan değil, sözleşmeden doğan davada müvekkilin noxal terketme hakkı olmaksızın sorumlu tutulabilmesi için gerekli olan koşulları belirleme sonunundan kaynaklanmaktadır.

Sonuç olarak, somut olay adaletini gerçekleştirmek için Klasik Dönem hukukçularının noxal sonuçlu sözleşmeden doğan davaya izin verdikleri söylenebilir. Hırsızlığın mağduru olan vekil, hırsızlık suçunun işlendiği anda, şeklen de olsa, hırsız kölenin maliki oldugu için noxal sonuçlu haksız fiil davasını açamıyordu. Çünkü, bu dava sadece kölenin efendisine, yani malike karşı açılabiliyordu. Kölenin hırsızlı̆̆ı nedeniyle efendiye (malike) karşı dava açılmasının kökeninde, efendinin köle üzerindeki mutlak egemenliginin zedelenmemesi ve fakat magdurun da zararının karşılanması gerektiği düşünceleri yatmaktaydı ${ }^{33}$.

Klasik Hukuk Dönemi'nde hem malik hem de mağdur (zarar gören) sıfatlarını aynı anda taşıyan vekilin actio furti noxalis'i açamaması engelinin, somut olay adaletini gerçekleştirmek amacıyla, sözleşmeden doğan davaya noxal etki tanınması yoluyla aşılmaya çalışıldığı görüşü akla yatkın gelmektedir.

${ }^{33}$ Biondi, Noxa, s. 449; Buckland, Slavery, s. 112-113. 


\section{KISALTMALAR}
Absch. : Abschnitt
AcP : Archiv für die civilistische Praxis
Afr. : Africanus
Aufl. : Auflage
Bas. : Basilika
Bd. : Band
Bkz. : Bakınız
D. : Digesta
dn. : dipnot
Gai.Ins. : Gaius Institutiones
M.S. : Milattan Sonra
NDI : Novissimo Digesto Italiano
Paul. : Paulus
Pomp. : Pomponius
RIDA : Revue internationale des droits de l'antiquité
s. : sayfa
SZ : Zeitschrift der Savigny-Stiftung für Rechtsgeschichte, romanistische Abteilung
TvR : Tijdschrift voor rechtsgeschiedenis
Vol. : Volume 


\section{YARARLANILAN KAYNAKLAR}

Berger, A.: Encyclopedic Dictionary of Roman Law, Philadelphia 1953

Biondi, B.: Iudicia Bonae Fidei I, Palermo 1920 [Iudicia]

Biondi, B.: Noxa, NDI 12, Milano VTET, s. 449-450 [Noxa]

Buckland, W. W.: Digest XLVII 2 (De Furtis) and the Methods of the Compilers, TvR 10, Groningen 1930, s. 117-142 [Slavery]

Buckland, W. W.: The Roman Law of Slavery, Cambridge 1908

Bund, E.: Untersuchungen zur Methode Julians, Köln 1965

Eisele, H. J.: Die Haftung des Mandanten für Schaden des Mandatars, AcP 84, Leipzig 1895, s. 319-357

Heldrich, K.: Das Verschulden beim Vertragsabschluß im klassischen römischen Recht und in der späteren Rechtsentwicklung, Leipzig 1924

Honsell, H.: Quod Interest im Bonae-Fidei-Iudicium, Studien zum römischen Schadensersatzrecht, München 1968

Karadeniz-Çelebican, Ö.: Roma Hukuku (Tarihî Giriş -KaynaklarGenel Kavramlar- Şahsın Hukuku- Hakların Korunması), 7, basım, Ankara 2001

Kaser, M.: Das Römische Privatrecht (das altrömische, das vorklassische und klassische Entwicklungen), 1. Absch., 2. Aufl., München 1971

Kübler, B.: Die Konträrklagen und das Utilitätsprinzip, SZ 38, Weimar 1917, s. 73-113

Lambert, J. N.: "Une opposition peu connue entre Sabiniens et Proculiens, Studi in Onore di Emilio Betti, Vol. III, Milano 1962, s. 279-296

Lenel, O.: Afrikans Quästionen Versuch einer kritischen Palingenesie, SZ 51, Weimar 1931, s. 1-53 [SZ 38]

Lenel, O.: Culpa lata und culpa levis, SZ 38, Weimar 1917, s. 263-290

Mac Cormack, G.: The Thievish Slave, RIDA 19, 3. Seri, Bruxelles 1972, s. 345-365

Medicus, D.: Id Quod Interest, Studien zum römischen Recht des Schadensersatzes, Köln 1962 
Noda, R.: Die Haftung des Auftraggebers für Schäden des Beauftragten. Zur Entstehung des $\$ 650$ (3) des japanischen BGB, FukuokaSymposium 1991, s. 207-231

Nörr, D.: Die Entwicklung des Utilitätsgedankens im römischen Haftungsrecht, SZ 73, Weimar 1956, s. 68-119

Pernice, A.: LABEO, Römisches Privatrecht im ersten Jahrhunderte der Kaiserzeit, Bd. II, 2, 1, Halle 1900

Stein, P.: Fault in the Formation of Contract in Roman Law and Scots Law, Edinburgh 1958

Thomas, J. A.: Pro Noxal Surrender, Labeo Rassegna di Diritto Romano 17, Napoli 1971, s. 16-32

Watson, A.: Contract of Mandate in Roman Law, Oxford 1961

Zilelioğlu, H.: Roma Hukukunda Gözetim (Custodia) Sorumluluğu, Yayınlanmamıs Doktora Tezi, Ankara 1985 